\title{
Férula quirúrgica intermedia en cirugía ortognática bimaxilar: Un método simple de obtención.
}

\author{
The intermediate surgical splint in bimaxillary surgery. A simple method for obtaining it
}

Estimado Director:

Ante todo quiero, en nombre de los autores, agradecerle a usted y al resto del Comité Editorial de la Revista Española de Cirugía Oral y Maxilofacial la deferencia que han tenido al publicar el trabajo: "Férula quirúrgica intermedia en cirugía bimaxilar. Un método simple de obtención".

Respecto a la "Discusión" que acompaña al artículo, y acogiéndonos a la oportunidad de respuesta que se ofrece a los autores en la Normas de Publicación, nos permitimos remitirle nuestros puntos de vista, confiando en que se estime oportuna su publicación.

Agradecemos el interés que demuestra el autor de la discusión, fruto de su indudable prestigio. Estamos de acuerdo con él en los conceptos fundamentales que le sirven de introducción; no obstante, nos atribuye errores que debemos rebatir.

Se nos dice que intentamos simplificar el movimiento de reposición del modelo maxilar usando como referencia la mandíbula en vez del plano de Frankfort, y que afirmamos que la posición de la mandíbula es invariable durante el proceso de simulación; para añadir a continuación que estamos en un error.

No estamos de acuerdo. En cualquier articulador semiajustable, el movimiento mandibular lo proporciona el brazo superior. En el procedimiento clásico de obtención de la férula no es correcto variar la dimensión vertical (puesto que el eje posterior de bisagra no es fiable) y, además, no se realizan movimientos condilares porque no se precisan. Solo se actúa con la segueta de corte a nivel del zócalo superior. Hemos de reconocer, por tanto, que la mandíbula permanece inmóvil en relación a la base del cráneo (plano de Frankfort o brazo superior del articulador) y a todo lo que le rodea.

No en vano escribimos reiteradamente que la dimensión vertical cráneo-mandibular preoperatoria debe ser igual a la dimensión cráneo-mandibular postoperatoria con la férula en posición. Es un concepto capital.

Más adelante, en la discusión se dice: "...si hay algo importante en la planificación de los movimientos maxilomandibulares, es la posición del maxilar..." y que: "...difícilmente podremos alcanzar el objetivo, si en la planificación, la cara y el complejo máxilomandibular no han sido relacionados..."

Por supuesto, estamos totalmente de acuerdo. La planificación de la cirugía se basa, exclusivamente, en la posición del maxilar en relación óptima con el resto del cráneo y cara. Esta posición la obtenemos en el estudio de la cefalometría (punto A, plano oclusal, etc.) y de la clínica (frente y perfil, línea media, línea labial, línea de sonrisa, etc.), así como de las características intrínsecas del plano oclusal superior. Es un concepto tan básico y estamos tan de acuerdo con él, que podríamos afirmar que (aunque cause extrañeza leerlo) para obtener las conclusiones que buscamos, la telerradiografía
Dear Sir,

I would first like to thank you and the rest of the Editorial Committee of the "Revista Española de Cirugía Oral y Maxilofacial", on behalf of the authors, for your courteous regard on publishing the work "The Intermediate Surgical Splint in Bimaxillary Surgery. A simple method for obtaining it."

With regard to the "Discussion" that accompanies the article, and given the opportunity in the Publication Guidelines that is offered to the authors to respond, we would like to give you our point of view, in the hope that it is considered suitable for publishing.

We appreciate the interest shown by the author in the discussion, which is the fruit of his undoubted prestige. We agree with him on the fundamental aspects that he gives as an introduction. Nevertheless, we are attributed errors that we feel we should reject.

We are told that we try to simplify the repositioning movement of the maxillary model using as a reference the mandible instead of the Frankfort plane, and that we state that the position of the mandible is invariable during the simulation process. It is then added that we are mistaken.

We do not agree with this. In any semi-adjustable articulator, the upper arm provides the mandibular movement. In the classical procedure used for obtaining the splint it would not be correct to vary the vertical dimension (as the posterior hinge axis is not reliable) and, in addition, condylar movements are not carried out because they are not needed. Only the cutting handsaw* is used on the upper platform. We should therefore recognize that the mandible remains immobile in relation with the skull base (Frankfort plane or upper arm of the articulator) and everything that surrounds it.

It is not without reason that we reiterate that the preoperative vertical craniomandibular dimension should be the same as the postoperative craniomandibular dimension with the splint in place. This is an essential concept.

Further on in the discussion it is stated that "If there is anything of importance in the planning of maxillomandibular movements, it is the position of the maxilla..." and that "reaching the objective would be difficult if in the planning the face and maxillomandibular complex have not been related.

We are of course in total agreement. The planning of the surgery is based exclusively on the maxilla being in the optimal position with regard to the rest of the skull and face. This position will be obtained in the cephalometric (point $A$, 
de perfil sería útil aunque en ella "no apareciera el hueso mandibular".

Obtengamos correctamente los cambios que precisa el maxilar y ya corregiremos posteriormente la mandíbula para obtener la oclusión final.

Con nuestro posicionador no estamos estudiando el caso. El caso "ya" está estudiado; sabemos cuánto y cómo hay que mover el maxilar; lo único que vamos a hacer es: realizarlo. No cuestionamos el diagnóstico, ni la indicación, ni el procedimiento. Sólo garantizamos el resultado, es decir, fabricamos la férula.

El articulador semiajustable está concebido para poder realizar pequeñas correcciones de la dimensión vertical y movimientos condilares de protrusiva, trabajo y balanceo. Con el arco facial se montan los modelos relacionados espacialmente con los cóndilos y el plano de Frankfort. Si en el procedimiento clásico de obtención de la férula no debemos alterar la dimensión vertical y tampoco movemos los cóndilos: ¿para qué queremos un articulador? ¿tal vez por la referencia al plano de Frankfort? ¿va a influir el susodicho plano en el trazado del corte quirúrgico, o será más correcto decir que el corte/plano quirúrgico será el que marque el escoplo en su recorrido por el suelo de la fosa nasal?.

Si eso es así, montemos el plano oclusal del modelo maxilar con su angulación respecto a espina nasal anterior - espina nasal posterior (plano palatino) y movamos el fragmento del Le Fort que obtendremos en el quirófano, según los parámetros obtenidos previamente.

Es obvio que la férula así obtenida será más fiable que si la obtenemos mediante el segueteado de una línea trazada paralela al plano de Frankfort en el zócalo del modelo maxilar, que difícilmente va a coincidir con la angulación del corte óseo.

En resumen, pensamos que la "Discusión" cuya réplica nos ocupa está basada en conceptos totalmente correctos, pero que no modifican los argumentos en que se basa el posicionador del maxilar que defendemos. Ambas filosofías son ciertas y no excluyentes; simplemente, alcanzan el objetivo previsto por procedimientos distintos $y$, en nuestro caso, obtenemos mayor fiabilidad con una metodología extraordinariamente simple.

José V. Pascual Gil occlusal plane) and in the clinical (forehead and profile, midline, lip line, smile lines, etc.) as well as from the intrinsic characteristics of the upper occlusal plane. This is such a basic concept, and our agreement with it is such, that we could even affirm (though it might appear strange to read this) that in order to obtain the conclusions that we are looking for, dental skull lateral teleradiography would be useful even if "the mandibular bone were not to appear in it."

The changes required in the maxilla should be obtained correctly and the mandible can later be corrected in order to obtain the final occlusion.

With our positioning device we are not studying the case. The case has "already" been studied; we know how much and in what way the maxilla has to be moved.; the only thing that we have to do is: perform this. We do not question the diagnosis, the application, or the procedure. We only guarantee the result. That is to say, we make the splint.

The semi-adjustable articulator has been conceived so that small corrections in the vertical dimension can be carried out together with condylar protrusive, working and balancing movements. The models are mounted with a space relationship between the facial arch and the condyles and Frankfort plane. If one should not change the vertical dimension or the condylar movements with the classical method for obtaining a splint: why do we need an articulator? For the Frankfort plane reference, perhaps? Will this plane influence the way the surgical cut is made, or would it be more correct to say that the surgical cut/plane should be the one dictated by the chisel as it crosses the floor of the nasal pit?

If this is the case, we should mount the occlusal plane of the maxillary model at an angle that is in relation with the anterior nasal spine- posterior nasal spine (palatine plane) and we should move the Le fort fragment that we will obtain in the operating room, according to the previously obtained parameters.

A splint obtained in this way will obviously be more reliable than if it is obtained by means of sawing along a line that had been traced parallel to the Frankfort plane on the platform of the maxillary model, which will hardly coincide with the angle at which the bone is cut.

In short, we feel that the "Discussion" we are replying to is based on concepts that are completely correct, but that these do not modify the arguments on which the maxillary positioning device is based. Both philosophies are correct and do not exclude each other; they simply reach the objectives set out through different procedures and, in our case, we obtain a much more reliable by using a method that is extraordinarily simple. 